\title{
Monthly variation in the morphological characteristics of Trichodina sp. (Ciliophora: Peritrichida) found on whiting Merlangius merlangus euxinus
}

\author{
Variación mensual de las características morfológicas de Trichodina sp. (Ciliophora: \\ Peritrichida) en el merlan Merlangius merlangus euxinus
}

\section{Hamdi Ogut $^{1}$ and Cemil Altuntas ${ }^{1}$}

\begin{abstract}
${ }^{1}$ Department of Fisheries Technology Engineering, Faculty of Marine Sciences Trabzon, Karadeniz Technical University, Turkey. oguth@ktu.edu.tr
\end{abstract}

\begin{abstract}
To determine the existence and extent of seasonal variation in morphological characteristics of Trichodina sp., sixty whiting Merlangius merlangus euxinus were sampled monthly for one year, from the Eastern Black Sea coast of Turkey, using a line and hook. Strong seasonal morphological variations were detected; the denticle span, blade length and ray length showed significant seasonal variation, especially in J une. The timing of primary production in the Black Sea and the changes in cellular organelles suggested a negative relationship between the body diameter of trichodinids and food availability in the surrounding environment.
\end{abstract}

Key words: Seasonal variation, morphology, primary production, Gadidae

\section{INTRODUCTION}

Trichodinids are ectozoic species and like other ectozoic ciliates they do not feed on their fish host, but glide on their host's surface to collect free swimming bacteria in the water column (Van As \& Basson 1995). Any decrease in the number of bacterial biomass in the environment could lead to a decreased number of trichodinids. Moreover, it could be possible that these organisms might respond to changes in food availability by adjusting their cell size to a specific extent.

Various studies have reported that the morphology of the trichodinids may change over seasons or host species. Thus, seasonal variability on morphology was first reported by (Kazubski \& Migala 1967), and later by Kazubski \& Migala (1968) in Trichodina nigra, T. domerguei and T. mutabilis. The most astounding result reported was that, in the winter, the size of the cells was $1 / 3$ larger than that of summer cells. In both reports, the findings indicated a seasonal fluctuation in the size of various cell components of trichodinids, although the sampling frequency and size were not large enough to draw any conclusions.

Even though the species description of trichodinids is based mainly on the morphological structures, there is no extensive report describing seasonal variations of the same species on the same host and factors affecting this variation. If the cell size of the same species is approximately 33\% larger in winter than that in summer (Kazubski \& Migala 1968), the variation in the morphology and the factors driving this variation deserve more intensive research for an appropriate description of trichodinid species. Here, in this study, we investigated the seasonal morphological variation of Trichodina sp. collected monthly from gills of Merlangius merlangus euxinus (Nordmann, 1870).

\section{Materials AND METHODS}

Sixty whiting, Merlangius merlangus euxinus, were captured monthly from August 2003 to July 2004 in the South Eastern Black Sea, Turkey, by line and hooks ranging from 25 to $35 \mathrm{~m}$ in depth. Fresh gill smears from all fish sampled were prepared on the vessel, air-dried and fixed with absolute ethanol for $5 \mathrm{~min}$. They were then stained with the dry silver impregnation technique described in Lom (1958) with slight modification. A sample of 15-20 trichodinid photomicrographs was compiled randomly from the smears of 60 fish per month from two capturing sites.

Some samples were stained with carbo-fuchsin. This procedure involved fixed samples being washed for 10 min, hydrolyzed for $2 \mathrm{~h}$ with $5 \mathrm{~N} \mathrm{HCl}$, dipped into $0.1 \mathrm{HCl}$ 
for a second, dipped in Shiff reagent for $2 \mathrm{~h}, 3 \times 5 \mathrm{~min}$ incubation in metabisulpide solution, washed for $10 \mathrm{~min}$ at tap water, washed $3 \mathrm{x}$ with double distilled water, dehydrated with a series of alcohol $(70 \%, 85 \%, 90 \%$ and $100 \%$ ) and observed under the microscope after closing with Canadian Balsam.

The photomicrographs were taken using a microscope (Nikon Eclipse 600) equipped with a camera. Measurements of morphological structures of trichodinids follow the descriptions of Lom (1958), Arthur \& Lom (1984), and Van As \& Basson $(1989,1992)$ (Fig. 1a). Measurements $(\mu)$ were carried out in Photoshop 6.0 (Adobe Systems Inc.). All specimens were measured twice, the variances in the measurements of each organelle were compared and a third measurement was carried out as final data of morphological components. In all samples, young cells of the trichodinid species studied were ignored (Ogut \& Palm 2005).

Averages of monthly measurements for each component were compared using Fisher's LSD test after the data was checked for normality and equal variances. Statview 5.0 (SAS Institute Inc.) was used to carry out statistical analyses and $P$-values less than 0.05 were considered to be statistically significant.

\section{Results AND Discussion}

A single species, Trichodina sp., was dominant on the Merlangius merlangus euxinus (Fig. 1b) in the monthly samples. Trichodina puytoraci (Lom 1962) and $T$. claviformis (Dobberstein \& Palm 2000) were two other species detected in $1.9 \%$ of the samples. Because these species were observed sporadically in some months, these species were not morphologically analyzed monthly.

\section{DESCRIPTION OF THE SPECIES}

Trichodina sp. is characterized by a small size and cupshape. Morphometric measurements are given in Table 1. The central zone of the adhesive disc in adult cells is partly clear with several scattered small dark granules, whereas some cells have a large shapeless dark cluster in the centre of the central zone. The white area is not thoroughly circular instead presenting several loop-like structures. The macronucleus is C-shaped, determined by carbo-fuchsin staining and its external diameter is between 28 and $37 \mu \mathrm{m}$ (14 measurements). Adoral ciliary spiral turns $367^{\circ}$ around the peristomial disc.
A

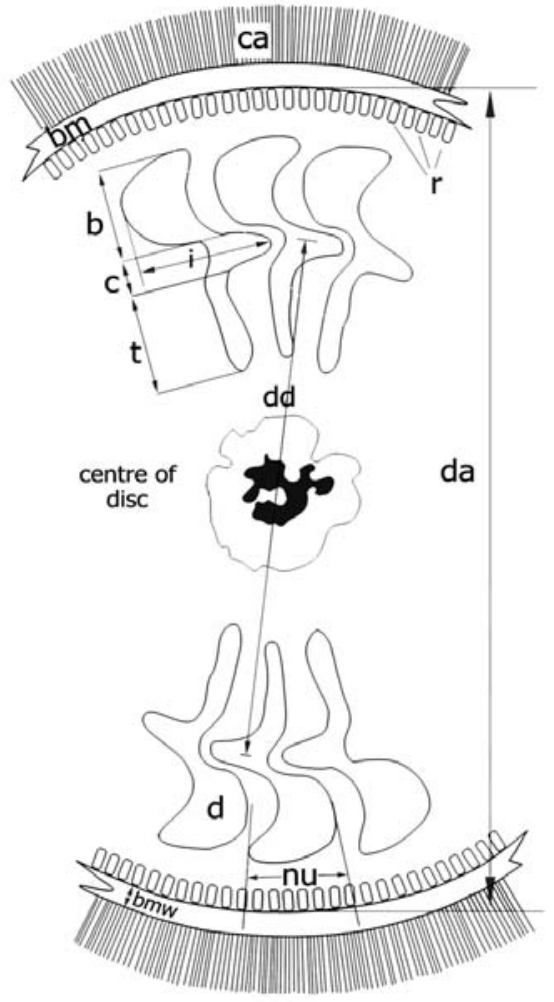

B

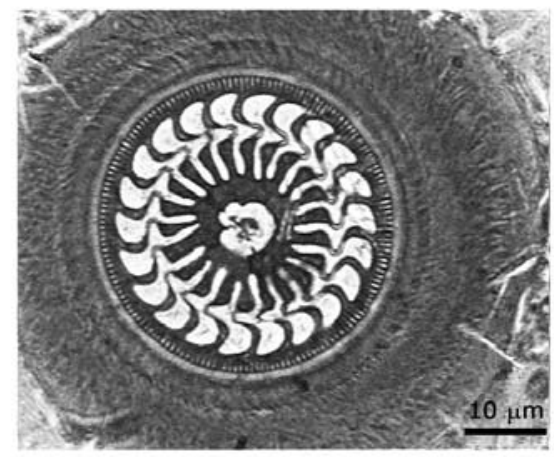

Figure 1. A. Measuring organelles in trichodinids; ca: cilia of adoral zone, bm: border membrane, r: radial pins, dd: denticle diameter, da: diameter of adhesive disc, d: denticle, nu: number of radial pins, bmw: border membrane width, b: blade length, $c$ : width of the central part, t: ray length, i: denticle span. $B$. Photomicrograph of dry silver impregnated Trichodina sp., found on Merlangius merlangus euxinus / A. Medidas de organelos en trichodinos; ca: cilios de la zona adoral, bm: borde de membrana, $r$ : dientes radiales, dd: diámetro del dentículo, da: diámetro del disco adhesivo, d: dentículo, nu: número de dientes, bmw: ancho del borde de membrana, b: longitud del aspa, c: ancho de la parte central, t: longitud del rayo, i: ancho máximo del dentículo. B. Microfotografía de Trichodina sp., con la técnica de plata impregnada, en Merlangius merlangus euxinus 
Table 1. Average ( \pm standard deviation, SD) and range (minimummaximum value) of morphometrical measurements $(\mu \mathrm{m})$ for 35 randomly selected individuals of Trichodina sp. found on Merlangius merlangus euxinus / Promedio ( \pm desviación estándar, SD) y rango (valores mínimo-máximo) de medidas morfométricas $(\mu \mathrm{m})$ de 35 individuos de Trichodina sp., elegidos al azar, en Merlangius merlangus euxinus

\begin{tabular}{lccc}
\hline Morphological Part Measured & Average $( \pm$ SD) & Range (Min - Max) & $\mathrm{n}$ \\
\hline Body diameter & $38.78 \pm 2.64$ & $34.53-42.34$ & 35 \\
Body width: height ratio & 1 & 1 & 10 \\
Adhesive disc diameter & $36.26 \pm 2.68$ & $32.97-39.7$ & 35 \\
Border membrane width & $1.49 \pm 0.37$ & $0.66-2.04$ & 35 \\
Denticle ring diameter & $22.93 \pm 2.01$ & $19.52-25.23$ & 35 \\
Denticle number & $24.38 \pm 1.26$ & $22-27$ & 35 \\
Radial pins per denticle & $5.54 \pm 0.52$ & $5-6$ & 35 \\
Denticle span & $9.59 \pm 0.48$ & $8.83-10.39$ & 35 \\
Denticle length & $4.53 \pm 0.33$ & $3.69-4.98$ & 35 \\
Blade length & $2.48 \pm 1.5$ & $0.81-4.26$ & 35 \\
Width of central part & $2.02 \pm 0.28$ & $1.5-2.4$ & 35 \\
Ray length & $3.68 \pm 0.27$ & $3.3-4.2$ & 35 \\
\hline
\end{tabular}

\section{MORPHOLOGICAL VARIATION}

There were seasonal variations in the sizes of some morphological characteristics of Trichodina sp. such as the denticle span, blade length and ray length (Fig. 2), whereas some structures (i.e., denticle length, denticle number, adhesive disc diameter and denticle ring diameter) did not change by seasons or by month (Fig. 2). The size of the denticle span gradually decreased from March to July. The size sharply increased in the following month, and then in September an initiation of gradual decrease to December was anticipated. The size of the denticle span from June to July (Summer) was significantly lower than that in March (Spring) and September (Fall) (Fisher's LSD test, $P<0.05$ ) (Fig. 2). Of the two denticle span features (blade length and ray length), variations in the blade length more closely followed the size variation of the denticle span ( $r=0.61, P<0.05$ ) (Fig. 2). The size of the ray length, dipping in May (Spring), gradually increased to a peak in August (Late Summer) (Fig. 2). The longest rays were measured from the cells captured in August, compared to those captured in other months (Fisher's LSD test, $P<0.05$ ). There were no statistically significant differences in mean denticle lengths between months (Fisher's LSD Test, $P>0.05$ ) (Fig. 2).

The monthly variations of body diameter, adhesive disc diameter, the denticle ring diameter, and number and length of the denticles followed the same trend. Increases and decreases in all above-mentioned morphological structures occurred in parallel throughout the year. Even though no significance was detected, the largest cells $(39.3 \pm 0.06 \mu \mathrm{m})$ were observed in January and the smallest cells $(35.96 \pm 1.17 \mu \mathrm{m})$ were captured in December. Interestingly, seasonal fluctuations of denticle numbers followed a similar pattern to that of body length, adhesive disc diameter, denticle ring diameter, and denticle length.

Body length of trichodinids was significantly correlated with adhesive disc diameter ( $r=0.95, P<0.05$ ), body membrane width, denticle ring diameter and central part width. Denticle span was significantly correlated with border membrane width $(r=0.62, P<0.05)$ and radial pins per denticle ( $r=0.85, P<0.05$ ). Body length, on the other hand, was not correlated with the denticle number $(\mathrm{r}=$ $0.41, P>0.05)$, denticle span $(\mathrm{r}=0.44, P>0.05)$ and radial pins per denticle $(r=0.47, P>0.05)$.

There were inter- and intra-seasonal variations in morphological structures of Trichodina sp. found on the whiting. As reported earlier, morphology of trichodinid species on a given host species changes seasonally (Laird 1953, Kazubski 1967, Kazubski \& Migala 1968). As reported by Kazubski \& Migala (1968), responses of some species to seasonal changes are more dramatic than others. In the latter study, it was reported that the size of some cells in the summer were at least $33 \%$ smaller than that of the cells from winter. Laird (1953) showed seasonal differences in denticulate ring diameter and number of denticles of T. parabranchicola. Similarly, Kazubski (1967) and Kazubski \& Migala (1968) reported significant seasonal differences in the numbers of denticles and their shapes in the winter and summer cells of Trichodina nigra. In the latter, it was also mentioned, as a general rule, both smaller and bigger individuals could have a low or high number of denticles. That is, the denticle number did not depend on the cell size, in parallel with our findings. In the present study, seasonal change of denticle numbers had a similar fluctuation pattern to that of body length, adhesive disc diameter, denticle ring diameter, and denticle length.

The underlying processes causing morphological variability in cellular structures of trichodinids is not known. Kazubski \& Migala (1968) speculated that the variability is a result of fission earlier or later than paternal individuals. A new skeletal ring is formed on a smaller or larger circumference than in the paternal individuals. As a result, the number of denticles on the new cell increases (Martins et al. 2010). Kazubski \& Migala (1968), moreover, speculated that temperature could be the reason igniting 

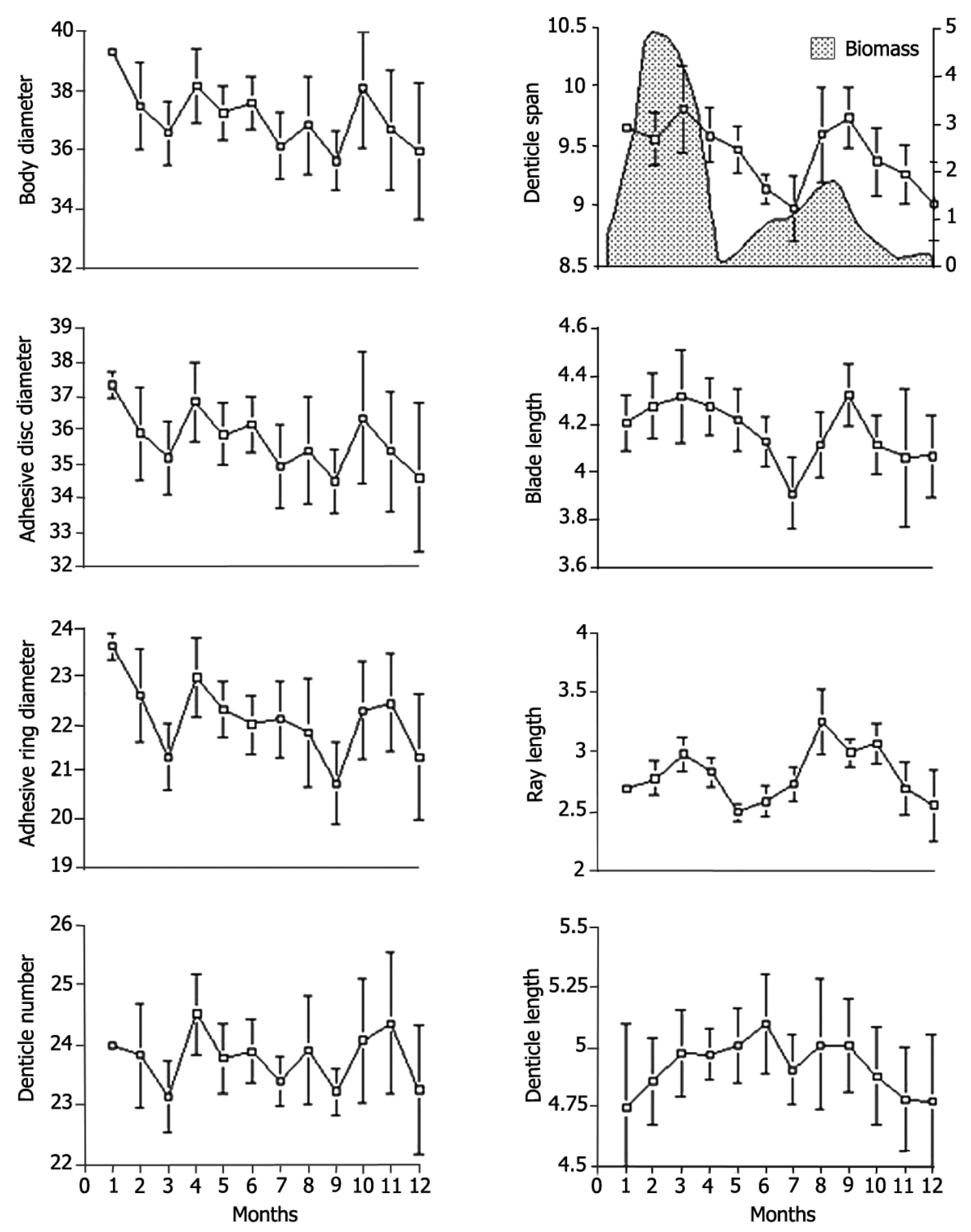

Figure 2. Monthly variation ( $1=\mathrm{J}$ anuary to $12=$ December) in cellular structures of Trichodina sp. found on the Merlangius merlangus euxinus from the Black Sea. Bars show $95 \%$ confidence intervals. The data for the biomass was redrawn from Sorohin (1983) / Variación mensual $(1=$ enero hasta $12=$ diciembre) de las estructuras celulares de Trichodina sp. en Merlangius merlangus euxinus obtenidos del Mar Negro. Las barras representan el 95\% de los intervalos de confianza. Datos de la biomasa fueron obtenidos de Sorohin (1983) 
the process. However, we found that larger cells could be found both in the winter and in the late summer, so that temperature itself cannot be the only causative reason having an effect (synergically or antagonistically) on the variability. We propose that primary production, or availability of food in the environments, may be the main cause driving the morphological changes. Sorohin (1983) reported that there were two peaks in primary production: one in January and the other, with smaller peak but longer duration, in July in the Black Sea. This seasonal fluctuation pattern was observed in denticle span, blade length and ray length, suggesting that when there is insufficient food, trichodinids respond by enlarging certain parts in new generations. Blade and ray size decrease when there is sufficient food and vice versa. It is possible that changes in the size of these organelles may provide for more efficient filtering of food items. The strongly seasonal change in the sizes of blade and ray especially suggests that the morphological changes are food-related in different seasons. The same approach might be true as well for explaining morphological differences in the same species at different localities. One locality may be more productive in terms of food for trichodinids than the other. Thus, the cells in less productive areas would be larger than in the highly productive areas. It could also be suggested that the same trichodinid species on different hosts could differ in morphology

Denticles of trichodinids are one of the main organelles of the cell. Factors affecting the number of denticles on a given species are in question. Kazubski \& Migala (1968) drew attention to the fact that the larger cells did not always have higher numbers of denticles than the smaller cells. We also found that the smaller cells could have higher numbers of denticles than a bigger cell at a given time regardless of the time of the year. Moreover, the change in the number of denticles followed a seasonal pattern parallel to the pattern observed in the diameter of the cell, adhesive disc and denticle ring. Interestingly, there are no studies mentioning changes in the denticle number and its possible link to feeding, or relating seasonal changes and feeding variation regimes. Considering that these protozoans are filter feeders, it can be suggested from the pattern of primary production that when food is scarce, the cell has a higher number of denticles than in times when food is plentiful. Thus, it can be hypothesized that the response of the protozoan is to have more denticles and have bigger cells to feed in environments poor in prey items. It should also be noted that, as Kazubski (1967) pointed out, the denticle number does not change with the age of the trichodinid but with new generations of the cells, supporting the hypothesis that, if food is getting scarcer, then new generations will be larger. More research is needed to determine the relationship between food availability and cell size or the size of other particulars.

In brief, changes in morphological characteristics of a same species of Trichodina were related to seasons. The concomitant occurrence of differences in the morphology, and timing of primary production suggests that food could be the main driving force for the observed changes/ fluctuations in the morphology. Therefore, our results suggest that in species descriptions, collection time, host and environment of the species need to be described.

\section{ACKNOWLedgments}

The project was supported by Karadeniz Technical University Research fund (Project 2003.117.001.5).

\section{LITERATURE CITED}

Arthur J \& J Lom. 1984. Some trichodinid ciliates (Protozoa: Peritrichida) from Cuban Fishes; a description of Trichodina cubanensis n. sp. from the skin of Cichlasoma tetracantha. Transactions of the American Microscopical Society 103: 172-184.

Dobberstein RC \& HW Palm. 2000. Trichodinid ciliates (Peritrichia : Trichodinidae) from the Bay of Kiel, with description of Trichodina claviformis sp. n. Folia Parasitologica 47: 81-90.

Kazubski SL. 1967. Study on the growth of skeletal elements in Trichodina pediculus. Ehrng. Acta Protozoologica 5: 37-48.

Kazubski SL \& K Migala. 1967. The seasonal variability in Trichodina. Journal of Protozoology 14: 35-36.

Kazubski SL \& K Migala. 1968. Urceolariidae from breeding carp Cyprinus carpio L. in Zabieniec and remarks on the seasonal variability of trichodinids. Acta Protozoologica 6: 137-159.

Laird M. 1953. The protozoa of New Zealand intertidal zone fishes. Journal of the Royal Society of New Zealand 81: 79-143.

Lom J. 1958. Contribution to the systematics and morphology of endoparasitic trichodinids from amphibians, with a proposal of uniform specific characteristics. Journal of Protozoology 5: 251-263.

Lom J. 1962. Trichodinid ciliates from fishes of the Rumanian Black Sea coast. Parasitology 52: 49-61. 
Martins ML, N Marchiori, G Nunes \&MP Rodrigues. 2010. First record of Trichodina heterodentata (Ciliophora: Trichodinidae) from channel catfish, Ictalurus punctatus cultivated in Brazil. Brazilian Journal of Biology 70(3): 637-644.

Ogut H \& HW Palm. 2005. Seasonal dynamics of Trichodina spp. on whiting (Merlangius merlangus) in relation to organic pollution on the eastern Black Sea coast of Turkey, Parasitology Research 96: 149-153.

Sorohin YL. 1983. The Black Sea. In: Ketchum BH (ed). Ecosystem of the world estuaries and enclosed seas, pp. 253-292. Elsevier, London.
Van As JG \& L Basson. 1989. Further contribution to the taxonomy of the Trichodinidae (Ciliophora: Peritrichida) and a review of the taxonomic status of some fish ectoparasitic trichodinids. Systematic Parasitology 14: 157179.

Van As JG \& L Basson. 1992. Trichodinid ectoparasites (Ciliophora: Peritrichida) of freshwater fishes of the Zambesi River system, with a reappraisal of host specificity. Systematic Parasitology 22: 81-109.

Van As JG \& L Basson. 1995. Trichodinidae and other ciliophorans (Phylum Ciliophora). In: Woo PTK (ed). Fish diseases and disorders. Protozoan and Metazoan Infections, pp. 1-158. CAB International Publishing, London.

Received 01 February 2011 and accepted 23 May 2011 